International Journal of Computer and Information System (IJCIS)

Peer Reviewed - International Journal

Vol : Vol. 02, Issue 04, September 2021

e-ISSN : 2745-9659

https://ijcis.net/index.php/ijcis/index

\title{
Automatic Door Control System With Body Temperature Sensor
}

\author{
$1^{\text {st }}$ Dwi Iskandar, $2^{\text {st }}$, Erik Wisnu Nugroho, $3^{\text {st }}$, Dewi Rahmawati, $4^{\text {st }}$, Ikhwan Rozikin \\ Information Systems \\ Indonusa Surakarta Polytechnic \\ Surakarta, Indonesia \\ dwik@poltekindonusa.ac.id,20erik.nugroho@poltekindonusa.ac.id,20dewi.rahmawati@poltekindonusa.ac.id, \\ ikhwan.rozikin@poltekindonusa.ac.id
}

\begin{abstract}
Conventional doors usually consist of a key housing and a key saddle to open it. In the current pandemic situation that has arisen due to COVID-19, so every human being is required to take precautions such as wearing a mask, keeping a distance, washing hands, not touching anything if not unnecessary. Research Methods Literature Study, Collection of supporting materials and tools, Program Design and Realization, Testing and Analysis of Program results, Making Final Report. The automatic door control system with a body temperature sensor is a prototype made to prevent the spread of COVID-19 by reducing direct physical contact that is spread through droplets attached to conventional doorknobs. Technology can be implemented in crowded areas such as shopping centers, offices, restaurants that are placed in indoor areas or indoor areas that are not exposed to direct sunlight. The components used are Arduino Uno Rev 3, Infrared Sensor, MLX90614 Temperature Sensor, 16x2 LCD, Buzzer, L298N Motor Driver, DC Motor, 12v Adapter, and LED
\end{abstract}

Keywords : COVID-19, automatic door, droplet

\section{INTRODUCTION}

In today's era, the development of science and technology plays an important role in human civilization. With the increase in knowledge and technology that is mastered or applied, it is hoped that humans can improve overall human welfare, although negative impacts always appear along with human technological advances. Today's technological developments can be seen that many tools have been created in order to provide convenience to the community in carrying out work. For example, to open and close a large door if done manually it will take a lot of time and energy. In this case, a tool will be made that can be used so that the door can open and close itself automatically.[1]

Conventional doors usually consist of a key housing and a key saddle to open it. Generally, the door can be made more practical in the office. The door will automatically open if there is a stimulus (physical energy) that moves it. For example, when someone wants to enter the room, the door will automatically open. Doors like this can be designed using automatic control using embedded system equipment such as microcontrollers. This automatic door system can be designed using automatic control combined with sensors and servo motors. In terms of input equipment, a PIR (Passive InfraRed Receiver) sensor is used which can detect humans approaching the door. This PIR sensor will send a signal to the Arduino process unit in which there is a microcontroller chip. The microcontroller will send the processed data to the Servo motor so that it can open and close the door automatically.[2]

In the current pandemic situation that has arisen due to COVID-19, so every human being is required to take precautions such as wearing a mask, keeping a distance, washing hands, not touching anything if not unnecessary. But something like tables, doors, vehicles etc. we touch so there is a possibility of spreading disease. On campuses and offices, people meet so there is a possibility of spreading disease by touching doors or other things that contain germs. This project is based on automation, where we will make an automatic door opening and closing mechanism (door to house/campus). Where the door opens when the sensor on the door is cut off then the mechanism is operated and opens the door and after closing automatically. So, there is no physical human touch with the door, so it will help prevent or reduce the spread of the COVID-19 pandemic disease.[3]

How it works is if a person's body temperature is below 37 degrees the door will open, but if the temperature is above 37 degrees the door will not open. So that people who have a high body temperature or lead to a fever, a warning sound will appear to warn the officers. Then it will be examined further. With this automatic door based on body temperature, it will reduce physical contact with temperature monitoring officers.

\section{RESEARCH METHODS}

In the implementation of this research, the method used is as shown in Figure 1The implementation methods include:

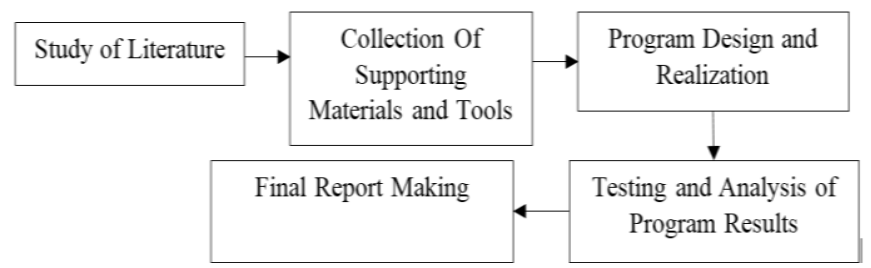

Figure 1. Research Methodology

The description of the flow above is:

1. Literature Study

Collecting library data, reading and taking notes, as well as managing research materials completely and thoroughly regarding the need for tools and materials to the manufacture of tools/products for the design of the system that will be made mature.

2. Collection of supporting materials and tools

Purchase tools and materials needed for the manufacture of tools/products.

3. Program Design and Realization 
Peer Reviewed - International Journal

Vol : Vol. 02, Issue 04, September 2021

e-ISSN : 2745-9659

https://ijcis.net/index.php/ijcis/index

Perform system design design and assemble tools according to designs that have been made with materials that have been purchased so that they can be applied according to designs that have been obtained from literature studies that have been carried out.

4. Testing and analyzing results

After the system is deemed sufficient at the manufacturing stage, the next step is to test and analyze the tool during testing, if there are improvements then a redesign is carried out, if there are improvements, redesign if not proceed to the report generation stage.

5. Making Final Report

Make a final report on the results of activities which are the last stage of implementation

\section{III.RESULT AND ANALYSIS}

\subsection{Prototype Overview}

The automatic door control system with a body temperature sensor is a prototype made to prevent the spread of COVID-19 by reducing direct physical contact that is spread through droplets attached to conventional doorknobs. Technology can be implemented in crowded areas such as shopping centers, offices, restaurants that are placed in indoor areas or indoor areas that are not exposed to direct sunlight. The components used are Arduino Uno Rev 3, Infrared Sensor, MLX90614 Temperature Sensor, 16x2 LCD, Buzzer, L298N Motor Driver, DC Motor, 12v Adapter, and LED.

In use, when the Infrared Sensor detects an object such as a human hand, it will activate the MLX90614 Temperature Sensor. After that, the MLX90614 Temperature Sensor will read how high the temperature of the object is so that the results of these readings will be displayed on a 16x2 LCD screen. When the temperature read is a normal temperature between $36-37{ }^{\circ} \mathrm{C}$ it will activate the DC Motor which has been fitted with gear to rotate so that the door can open automatically and the LED will light up for a few seconds as a sign of safety. When the recorded temperature is not normal, the DC Motor will not be activated but the Buzzer and LED will sound and flash several times within a few seconds as a warning signal. As for the design of the Realization Program, it can be seen in Figure 2.

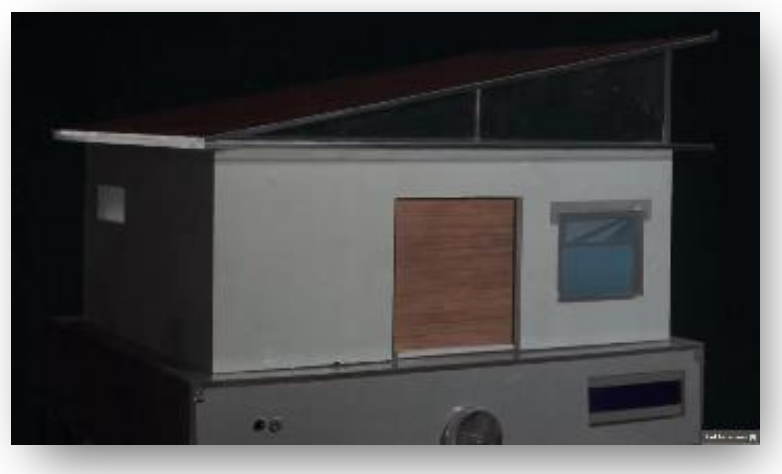

Figure 2. Program Realization

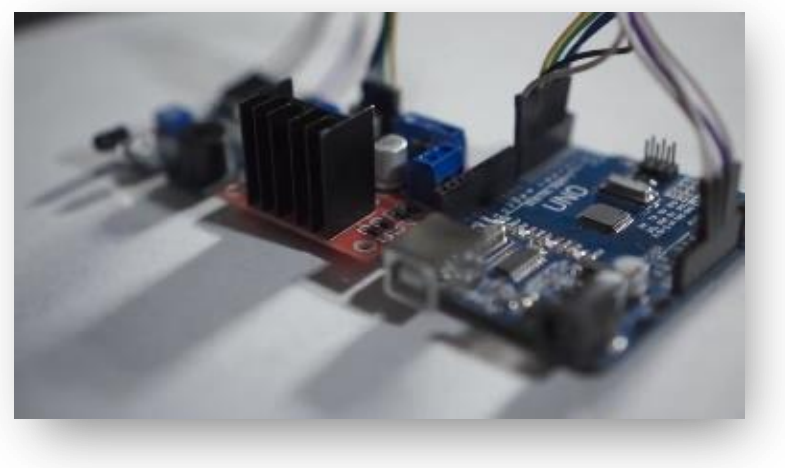

Figure 3. Component Circuit

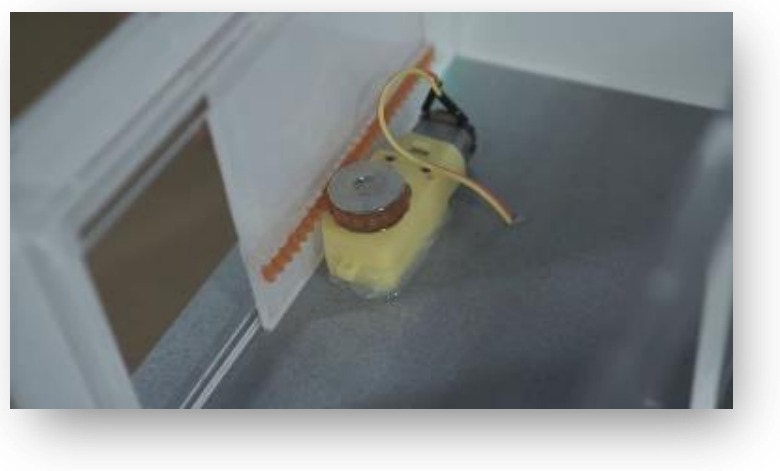

Figure 4. Sliding Door Activator

\subsection{Functions and How it Works}

The functions of this system are:

1. Provide comfort for temperature monitors and visitors

2. Reducing the physical contact of visitors with temperature monitoring officers with a more effective system.

3. As a solution to reduce physical contact in the covid-19 pandemic

The way this system works is:

1. Infrared sensor will detect objects (human hands). When the sensor reads an object, the infrared sensor will activate the MLX 90614 Temperature Sensor.

2. The MLX 90614 Temperature Sensor reads the object temperature and the temperature reading results will be displayed on a $16 \times 2$ LCD.

3. When the temperature is $37^{\circ} \mathrm{C}$, the DC Motor is not active which causes the door to not open and the Buzzer will sound as a notification if the temperature exceeds the normal limit and the LED will flash in a few seconds.

4. When the temperature is normal, the LED will light up continuously for a few seconds. Not only that, the DC Motor will rotate so that the door will open within a few seconds after opening, the DC Motor will rotate in the opposite direction so that the door will close again.

3.3 Advantages and Predicted Benefits for Users

The advantages of this system are:

1. Can be one of the newest options in implementing the COVID-19 health protocol, namely checking body temperature with a more effective system.

2. Provide comfort for temperature monitors and visitors. 
Peer Reviewed - International Journal

Vol : Vol. 02, Issue 04, September 2021

e-ISSN : 2745-9659

https://ijcis.net/index.php/ijcis/index

3. Can reduce the physical contact of visitors with temperature monitors.

4. Creating security and comfort for all visitors.

Predicted Benefits for Users, namely:

1. User can find out how high his body temperature is

2. Provide comfort for temperature monitors and visitors.

3. Can reduce the physical contact of visitors with temperature monitors.

4. Creating security and comfort for all visitors.

\subsection{Recording Results}

The results of this prototype test prove that the function level of this prototype can work at $100 \%$, with the following recording results. The Prototype Recording Results can be seen in table 1

Table 1. Prototye Recording Results

\begin{tabular}{|c|c|c|c|c|c|c|}
\hline $\begin{array}{c}\text { Trial } \\
\text { to }-\end{array}$ & $\begin{array}{c}\text { Infrared } \\
\text { Sensor }\end{array}$ & $\begin{array}{c}\text { MLX90614 } \\
\text { Suhu } \\
\text { Temperature } \\
\text { Sensor }\end{array}$ & $\begin{array}{c}\text { Tempera } \\
\text { ture } \\
\text { recordin } \\
\text { g results }\end{array}$ & $\begin{array}{c}\text { DC } \\
\text { Motor }\end{array}$ & Buzzer & LED \\
\hline 1 & active & active & 36,09 & Active & $\begin{array}{c}\text { not } \\
\text { active }\end{array}$ & $\begin{array}{c}\text { Light } \\
\text { up }\end{array}$ \\
\hline 2 & active & active & 37.24 & $\begin{array}{c}\text { not } \\
\text { active }\end{array}$ & active & Blink \\
\hline 3 & active & active & 36,00 & Active & $\begin{array}{c}\text { not } \\
\text { active }\end{array}$ & $\begin{array}{c}\text { Light } \\
\text { up }\end{array}$ \\
\hline 4 & active & active & 36,65 & active & $\begin{array}{c}\text { not } \\
\text { active }\end{array}$ & $\begin{array}{c}\text { Light } \\
\text { up }\end{array}$ \\
\hline 5 & active & active & 36,75 & active & $\begin{array}{c}\text { not } \\
\text { active }\end{array}$ & $\begin{array}{c}\text { Light } \\
\text { up }\end{array}$ \\
\hline
\end{tabular}

In these trials, the temperature sensor readings from the MLX90614 Temperature Sensor with Thermogun have been carried out side by side, it can be seen that the accuracy level of the temperature sensor readings with the MLX90614 Temperature Sensor is $94 \%$ with the following recording results:

Table 2. Temperature recording results

\begin{tabular}{|c|c|c|}
\hline \multirow{2}{*}{ Trial to - } & \multicolumn{2}{|c|}{ Temperature recording results } \\
\cline { 2 - 3 } & $\begin{array}{c}\text { MLX90614 Suhu } \\
\text { Temperature Sensor }\end{array}$ & Thermogun \\
\hline 1 & 36,06 & 36,26 \\
\hline 2 & 36.07 & 36,27 \\
\hline 3 & 36,10 & 36,34 \\
\hline 4 & 36,12 & 36,35 \\
\hline 5 & 36,07 & 36,28 \\
\hline Average & 36,08 & 36,30 \\
\hline Accuracy & & \multicolumn{2}{|c}{} \\
\hline
\end{tabular}

\subsection{Development Potential}

The prototype of an automatic door control system with a body temperature sensor can be developed into an even better tool. The development of this prototype will be developed by adding a database, camera, and thermal. The addition of the database is

used to provide daily reports of the results of temperature recording, from the report it can also be seen the average temperature recorded as well as the date and time of each recording. The addition of a camera is also used to detect whether the object or person is wearing a mask or not, the results will be displayed in the database as well. The addition of thermal will be used to replace the temperature sensor MLX90614 so that body temperature readings will be more accurate.

\section{CONCLUSION}

\subsection{Conclusion}

The automatic door control system with body temperature sensor has been completed. The design of this prototype uses an arduino microcontroller using the $\mathrm{C}$ programming language. The accuracy of the MLX90614 temperature sensor compared to a thermogun is $95 \%$, so that the sensor can be used as a body temperature measuring device. The test results on the prototype prove that all systems and components of the automatic door control system with body temperature sensors can work with a percentage level of $100 \%$. Therefore, an automatic door control system with a body temperature sensor can be implemented in crowded areas such as shopping areas, offices, restaurants that are placed in indoor areas or indoor areas that are not exposed to direct sunlight. In this study has shown significant results The accuracy of the MLX90614 temperature sensor compared to a thermogun is $95 \%$.

\subsection{Suggestions}

In the process of implementing this PKM, of course there are still some shortcomings, for that the author proposes the following suggestions for further research.

1. Using an automatic door control system with a body temperature sensor in crowded areas such as shopping areas, offices, restaurants and placed in an indoor area or indoor area that is not exposed to the sun directly

2. The temperature sensor used is the MLX90614 temperature sensor which can only measure the temperature of certain body parts placed on the front of the sensor. It would be better in the future to develop a measuring instrument using a thermal camera.

3. Added database and mask detector when someone takes body temperature. This is to make it easier to track the time of finding people whose body temperature exceeds the maximum limit when Covid-19 cases spread in the area.

\section{REFERENCES}

[1] Desmira, D. Aribowo, W. Dwi Nugroho, and Sutarti, "Application of Passive Infrared (PIR) Sensors on Automatic Doors at PT. LG ELECTRONIC Indonesia," $J$. PROSISKO, vol. 7, no. 1, pp. 1-7, 2020.

[2] N. Lestari, "Design and Build Automatic Doors Using Arduino Uno and PIR (Passive Infra Red) Sensors at SMP Negeri Simpang Semambang," J. Chem. Inf. Model., vol. 53, no. 9, pp. 1689-1699, 2017.

[3] V. K. Suravase, V. D. Shinde, D. T. Shirsat, S. S. Diwate, and S. N. Palhe, "Automation of Door Opening \& Closing," pp. 4-9, 2021, doi: 10.36227/techrxiv.14724801.v1.

[4] K. Adrian, "Understanding Body Temperature and How to Measure It - 2021. https://www.alodokter.com/memahami-suhu-tubuh (accessed Mar. 14, 2021)

[5] S. Prusty, "Arduino Based Home Automation Using Android," Int. J. Intell. Comput. Appl. Sci., vol. 5, no. December, pp. 23-26, 2017, doi: 10.13140/RG.2.2.20219.03360. 
International Journal of Computer and Information System (IJCIS)

Peer Reviewed - International Journal

Vol : Vol. 02, Issue 04, September 2021

e-ISSN : 2745-9659

https://ijcis.net/index.php/ijcis/index

[6] B. Varshini, H. Yogesh, S. D. Pasha, M. Suhail, V. Madhumitha, and A. Sasi, "IoT-Enabled Smart Doors for Monitoring Body Temperature and Face Mask Detection," Glob. Transitions Proc., pp. 0-17, 2021, doi: 10.1016/j.gltp.2021.08.071.

[7] Y. Kristyawan and A. D. Rizhaldi, "An Automatic Sliding Doors Using RFID and Arduino," Int. J. Artif. Intell. Robot., vol. 2, no. 1, p. 13, 2020, doi: 10.25139/ijair.v2i1.2706.

[8] M. R. Furqoni, " $\sqrt{ }$ Roda Gigi : Pengertian, Fungsi dan Jenisnya [Materi Lengkap]," 2021. https://teknikece.com/roda-gigi/ (accessed Jul. 09, 2021).

[9] R. A. Dalimunthe, "Alarm Based Electric Current Monitor With Current Sensor Using Arduino Uno . Microcontroller," Semin. Nas. R. 2018, vol. 9986, no. September, pp. 333-338, 2018.

[10] M. Padmarasan, B. Subhash, K. Karthikeyan, E. S. Rajkumar, P. Venkata, and V. Reddy, "Automatic open and close door for covid situation," pp. 328-332, 2021.

[11] Muqorobin, M., Hisyam, Z., Mashuri, M., Hanafi, H., \& Setiyantara, Y. (2019). Implementasi Network Intrusion Detection System (NIDS) Dalam Sistem Keamanan Open Cloud Computing. Majalah Ilmiah Bahari Jogja, 17(2), 1-9.

[12] Muryani, A. S., \& Muqorobin, M. (2020). Decision Support System Using Cloud-Based Moka Pos Application To Easy In Input In Orange Carwash Blulukan Flash N0. 110 Colomadu. International Journal of Computer and Information System (IJCIS), 1(3), 66-69. 